sua "lei": o "outro" é o inimigo a vencer pela subjugação ou pela eliminação. A natureza é mais um palco de conflito aberto que o paraíso da idílica convivência entre os contrários. Da filosofia grega em diante, com avanços e retrocessos, o bom combate tem sido no sentido de superar o "estado de natureza". Não faz, portanto, sentido encarar qualquer projeto de humanização como equivalendo ao movimento de retomada de uma essência natural perdida, de um ideal de pureza original. A humanização é a construção gradual de um projeto de pessoa e de vida coletiva no âmbito de um processo histórico. Hoje, o ser humano tem o extraordinário poder de tentar definir o que quer ser; tem como manipular, mudar o curso, do que parecia necessidade inelutável. Pode por isso, dentro de certos limites, se re-identificar e redesenhar novas relações com seus semel hantes. Pode dar realidade a muitas potencialidades. $\mathrm{N}$ ão tem como chegar à perfeição, mas pode perseguir a perfectibilidade.

Suponhamos que o indivíduo nada mais seja que uma marionete à mercê dos genes e dos símbolos. Se as diversas ciências levarem a este tipo de conclusão, ainda assim será válido pensar que o ser humano pode agir com algum grau de liberdade. E que pode aumentar o quantum de liberdade usufruído obtendo o conhecimento das causas que fazem do homem um fantoche do sistema social e da natureza impiedosa. E desde que lhe seja possível reverter, ainda que parcialmente, esse quadro. A liberdade seria o que é possível fazer por livre escolha descontadas as determinações superáveis. N o plano da vida social, o que se constata é que nem todas as determinações são, em termos valorativos, iguais. Há muitas formas de reagir psicológica e socialmente ao que é, por exemplo, econômica ou geneticamente causado. Se a ciência leva à descoberta de que o homem vive sob o jugo de férreas necessidades, uma possibilidade é a ataraxia, outra é procurar, respeitando os determinantes, estabelecer os melhores modos possíveis de viver e conviver. Por mais que sua bagagem genética escape a seu controle, a existência social condena o homem a fazer escolhas mesmo quando adota, dissolvendo sua identidade na manada, formas de ser ester eotipadas. Assumir a responsabilidade por seus atos, para além dos álibis da culpa sistêmica, é o que lhe resta fazer. Vale sempre a pena lembrar do Julius Caesar de Shakespeare: "The fault, dear Brutus, is not in our stars but in ourselves that are underlings".

\section{Natural e humano: encontros e desencontros}

$N$ atural and human: agreements and disagreements

\section{Everardo Duarte N unes 3}

H umanistic insight and scientific objectivity are not and never should be opposed: a devotion to humanistic values will lead to a more insightful science, and a equal devotion to scientific values will lead to a more convincing humanism. We are equal partners in the task of achieving a better understanding of mankind.

Robin Fox, 1996.

As duas citações que abrem, como epígrafes, 0 artigo de Ana M aria e M aria Cecília são emblemáticas e nos encaminham para um texto que se adensa à medida que as autoras desenvolvem um instigante, erudito e vibrante estudo da natureza humana, ciência e humanismo. São três temas que vão interagir mediados pela perspectiva da ética na definição da existência/essência humana. Calcada na visão espinosista do homem, revisa a notável contribuição de H enri Atlan que orienta a difícil discussão ciência versus humanismo.

M as, como comentar um texto tão completo e com idéias que são concordantes com 0 nosso pensar? Assim, envolvido pelo trabalho, procurarei refletir sobre o tema; afinal, um dos pontos básicos do kantismo e que agiu sobre a filosofia moderna e contemporânea foi o da reflexão sobre a ciência e em geral sobre as atividades humanas, a fim de determinar as condições que garantem (elimitam) a validade da ciência e em geral das atividades humanas (A bbagnano, 1952). Esta reflexão passa por algumas lembranças que permitirão alinhavar algumas idéias que estão no âmago do pensamento ocidental e foram traduzidas de diferentes maneiras.

A primeira desponta da visão oferecida pela magnífica síntese pictórica que Rafael (14831520) construiu em seu célebre afresco A Escola deAtenas (1509-1511), pintado a pedido do papa Júlio II, para a sua biblioteca no Vaticano. Autêntica expressão do Renascimento, recolocando o homem no centro do universo, con- 
densa de maneira extraordinária, como peça alegórica de plasticidade inigualável, o saber, a ciência, a arte de diferentes épocas e lugares em personagens emblemáticos: Platão, Aristóteles, Averróis, Pitágoras, Euclides, Zoroastro, Hipatia de Alexandria e muitos outros, em um total de 56 figuras. A forma teatral como Rafael colocou os grupos de personagens expressa conteúdos significativos: Platão, segurando o Timeu, aponta para o céu, gesto que representa a "teoria das formas" (abstrata e intangível); A ristóteles, portando a Ética, gesticula em direção à terra, o que representa a "percepção dos sentidos", base da sua teoria do conhecimento; Sócrates argumenta com as mãos estendidas para um grupo de atentos ouvintes; Rafael não excluiu os artistas da sua composição, que haviam sido expulsos da cidade por Platão em A República, pessoas que pensam de maneira alegórica, não rigorosa, "criador de aparências", e se auto-retratou ao lado de Ptolomeu, representando um dos seus discípulos artistas: o pintor grego Appeles; lá está, também, Pitágoras explicando a sua teoria musical. Certamente, o seu tributo às artes foi dado quando retratou $\mathrm{H}$ eráclito com o rosto de M ichelangelo, Euclides com a face de Bramante, ePlatão com a de Leonardo da Vinci.

A riqueza deste imenso afresco e as inúmeras possibilidades de leituras que se estendem aos domínios do diálogo interdisciplinar fica mais evidente quando se tem à frente um encarte da revista La Recherche, em seu número 300, ao ilustrar três séculos de ciência ( $L a R e$ cherche, 1997). N ele não há lugar para as humanidades. Estão presentes os cientistas: físicos, químicos, matemáticos, astrônomos, biólogos, e suas mais destacadas descobertas das ciências naturais.

0 afresco de Rafael tem cinco séculos e o pôster de Recherche é do final do século passado e capta três séculos de ciência, e nele a filosofia, a história, a antropologia, a sociologia foram abolidas. $\mathrm{N}$ ão há menção, nesse longo período, da invenção das ciências humanas, muito embora no Editorial desse número da revista, Dominique Pestre, diretor de pesquisa do CNRS (Centre de Recherche en $\mathrm{H}$ istoire des Sciences et des Techniques) aponte que Consagrada às ciências dos três últimos séculos, parte de idéia que a conduz a reencontrar a riqueza, 0 desenvolvimento, a diversidade do empreendimento Science au fil des temps, que faz redescobrir os sábios em suas obras, em seus mundos, em suas culturas, em seu tempo - em seus lugares (lieux) (Pestre, 1997). Em realidade, nos arti- gos solicitou-se aos autores que contassem sua história a partir dos espaços físicos e sociais, materiais e intelectuais, nos quais seus heróis inventaram e desenvolveram novos saberes. N ão discordamos da visão da história da ciência que perpassa pelos artigos, cuja dinâmica é vista a partir dos lugares onde a ciência é elaborada, nem da belíssima reconstituição feita pelos autores da história das instituições e dos personagens da ciência, incluindo, por exemplo, o trabalho de llana Löwy sobre "os missionários da febre amarela" no qual trata dos métodos autoritários dos especialistas americanos no Brasil (Löwy, 1997), mas da exclusão das ciências humanas e sociais per se.

Estes dois momentos levam-me a pensar em Dilthey (1833-1911) que, ao escrever, em 1833, um livro fundamental para as ciências humanas - Introdução ao estudo das ciências do espírito: ensaio sobre o fundamento que se poderia dar ao estudo da sociedade e da história - , traçou uma linha divisória entre as ciências. Concebe uma epistemologia autônoma das ciências humanas, proclamando a sua independência e, como diz Japiassu (1978), no momento em que a força catalisadora, em favor da autodeterminação epistemológica das ciências humanas [se revela na] tomada de consciência histórica das ciências humanas. Além de tomar como objeto das ciências humanas a política, 0 Estado, a sociedade, o direito, a religião, as línguas, a arte, Dilthey vai buscar na corrente hermenêutica o método capaz de conferir unidade às ciências humanas. Como lembram as autoras do texto, Dilthey inaugura o "descompasso" entre as ciências naturais e humanas, umas explicando a natureza, as outras compreendendo-a, o que mais tarde redundaria no que se denominou de "duas culturas", expressão criada por Charles Pierce Snow, em 1959. Aqui não se trata apenas de demarcar territórios, mas de verdadei ras batal has marcadas por acirrados ataques dos cientistas contra as humanidades, e destas em relação à hard science.

M uitos foram os estudiosos que se dedicaram a entender as "duas culturas", inclusive o próprio Snow retomaria a sua conferência dos anos 50. Sem dúvida, uma das melhores sínteses foi realizada pela Comissão Gulbenkian para Reestruturação das Ciências Sociais (1996), ao comentar a "realidade e val idade da distinção". N esse sentido, lembram que depois dos anos 60 ocorreram dois desenvolvimentos nas estruturas do saber: nas ciências naturais em relação aos princípios newtonianos e os rela- 
cionados à crescente incapacidade das teorias científicas mais antigas para fornecer soluções plausíveis aos cientistas diante dos problemas cada vez mais complexos. Para as ciências sociais, as questões se acentuam com a crítica ao modelo de epistemologia nomotética e, do lado das ciências naturais, a não linearidade em detrimento da linearidade, a complexidade em detrimento da simplificação, a impossibilidade de separar o medidor da medição, e até, no caso de alguns matemáticos, a superioridade da dimensão interpretativa e qualitativa sobre uma precisão quantitativa de rigor mais limitado. Como diz a Comissão, as ciências naturais estavam se parecendo mais com as soft sciences e as ciências sociais com as hard sciences. Com isto iniciava-se uma mudança no equilíbrio de poder vivido nas lutas internas das ciências sociais e a reduzir a distinção entre as ciências naturais e sociais, o que não implicou conceber a humanidade como algo de mecânico, mas antes conceber a natureza como algo de ativo e criativo ( $\mathrm{Co}$ missão Gulbenkian, 1996).

De ambos os lados tem havido aproximações, seja na aplicação dos sistemas complexos à análise das ciências sociais, seja na aplicação da flecha de tempo por parte dos estudiosos das ciências naturais. $M$ as, como concluem os analistas, Não se pode falar de uma verdadeira reaproximação entre as múltiplas expressões das duas (ou três) culturas [naturais, sociais e humanas]. Contudo, os debates havidos suscitaram dúvidas quanto à clareza das distinções (Comissão Gulbenkian, 1996). Como cito abaixo, os embates ainda continuam.

Em trabalho anterior (N unes, 2003), citei uma passagem de Hilary Rose, socióloga, ativista do movimento feminista e do movimento radical na ciência, que aqui repito pela oportunidade da análise por ela realizada: 0 s que se denominam defensores da Ciência estão procurando policiar as fronteiras do conhecimento e ressuscitar o conhecimento canônico da natureza, contra as tentativas dos O utros - incluindo feministas, anti-racistas, psicanalistas, pós-colonialistas, esquerdistas, multiculturalistas, relativistas, modernistas, etc. em toda nossa desconcertante diversidade - para estender, transformar ou talvez mesmo dissolver as fronteiras entre as privilegiadas pretensões de verdade da ciência e os outros conhecimentos (Rose, 1996).

Talvez eu tenha feito um longo percurso para repetir com outras palavras o dito, com muito mais propriedade, no artigo. $M$ as se assim agi, foi a fim de enfatizar um ponto central no trabal ho - o entendimento de dimensões que, se polarizadas, não trazem maiores contribuições ao conhecimento; e isto não tem partido somente dos humanistas. Ilya Prigogine, Nobel de Química, foi defensor intransigente do papel da criatividade nas ciências. Como escreveu nas conclusões de 0 fim das incertezas: Todos sabem que se Shakespeare, Beethoven ou Van Gogh tivessem morrido prematuramente, ninguém jamais teria realizado suas obras. Que dizer a este respeito dos cientistas? Se não tivesse havido um $\mathrm{N}$ ewton, alguma outra pessoa não teria descoberto as leis clássicas do movimento? (Prigogine, 1996).

Ao enfatizar esse ponto, não pretendo dizer que a questão se reduz ao pólo epistemológico, mas que o conhecimento das ciências naturais, sociais e humanas são fundamentais no dimensionamento de uma ética solidária e de respeito à vida. Nisso, o texto que temos em mãosé exemplar. As autoras buscam construir um raciocínio no qual a razão iluminista apareça como parte de "um mundo de liberdade e felicidade". Nada mais oportuno do que Spinoza para ensinar esse caminho que Atlan nos traduz de maneira a facilitar o percurso. $M$ as por que Spinoza? Recentemente, Ricardo Teixeira apresentou uma tese que trouxe para a área da saúde uma oportuna leitura desse filósofo, ao propor a idéia original de uma "hipotética medicina espinosana" que se caracteriza por "ser otimista em relação ao que se espera da natureza" e de criar, para os corpos e as almas, as melhores condições para que se amplie a potência humana de perfazer a verdade, a liberdade e a felicidade, alcançando, assim, a Grande Saúde (ou a Ética). (Teixeira, 2003).

Verifico, assim, a atualidade deste artigo, num momento em que o vigor das descobertas biológicas somente se completará se coexistir com as necessidades humanas, sociais e eticamente construídas, deixando de lado a pretensão de tentar dominar o conhecimento sobre a natureza humana. Este será o caminho para que "humanismo" e"humanização" sejam compreendidos, sem a necessidade de utilizarmos aspas, pois os seus significados terão a universalidade que tem sido patrimônio das ciências naturais. Assim, volto ao início deste texto. $\mathrm{Na}$ tela renascentista há equilíbrio e harmonia em saberes de distintas épocas e origens, captadas por Rafael, mas que acima de tudo em seu Elogio à filosofia (uma das denominações da $\mathrm{A}$ Escola de Atenas, assim chamada a partir do século 17 , originalmente nomeada Causarum Cog- 
nitio) expõe o ideal grego enklukio paidéia - as sete artes liberais essenciais à formação do homem grego, cujo princípio espiritual não é o individualismo, mas o humanismo, núcleo do pensamento da Renascença. M as esses ideais vão se perdendo, mesmo com a defesa utópica de Bacon e sua A nova Atlântida (1627), ou a busca da unidade do saber, que o Século das Luzes, ilustra com a Enciclopedie, no século 18. 0 século 19 é marcado não somente pelo crescente desenvolvimento científico, que se inicia no século 17, mas pela pulverização do saber e dos especialistas que adentra os séculos 20 e 21 .

Retomar a idéia de humanitas - sentido clássico e originário de humanismo, coloca-se como um ideal, congregando cientistas, artistas, literatos, filósofos, historiadores, e como uma prática necessária diante dos problemas e da contínua perda de valores morais, a fim de que se possa permitir a todos os seres humanos 0 acesso ao melhor de nossa herança desde Sócrates: aquela que contempla a capacidade deautoconhecimento, autodeterminação e autogestão de indivíduos e grupos sociais, de acordo com os ditames de sua verdadeira natureza, como brilhantemente as autoras encerram o seu trabal ho. Parabéns e obrigado pela oportunidade de ler e refletir sobre um tema contemporâneo e necessário.

\section{Referências bibliográficas}

Abbagnano N 1952. Dicionário de Filosofia. Tradução de Alfredo Bosi. M estre Jou, São Paulo.

Comissão Gulbenkian para Reestruturação das Ciências Sociais 1996. Para abrir as ciências sociais. Cortez Editora, São Paulo.

Fox R 1996. State of the Art/Science in Anthropology, pp. 327-334. In PR Gross, N Levitt e M W Lewis (ed.). The flight form science and reason. N ew York Academy of Sciences, N ova York.

Japiassu H 1978. Nascimento e morte das ciências humanas. Francisco Alves, Rio de Janeiro.

Löwy I 1997. Les missionnaires de la fievre jaune. La Recherche 300, juillet/aout:88-92.

N unes ED 2003. As ciências humanas e sociais e a saúde: algumas considerações. Revista Brasileira de Educação M édica 27(1), Jan/Abr:65-71.

Pestre D 1997. 300 ans de science - Lieux de science: laboratoires, observatories, academies, jardins, écoles, museums, industries, foundations ... La Recherche, 300 , Juillet-Aoüt: 26-27.

Prigoginel 1996. 0 fim das certezas: tempo, caos e as leis da natureza. Tradução de Roberto Leal Ferreira. Editora da Universidade Estadual Paulista, São Paulo.

Rose H 1996. M y enemy's enemy is - only perhaps - my friend, pp. 80-101. In A Ross (ed.). Science wars. Duke University Press, Dunham-Londres.

Teixeira RR 2003. Estudo sobre a técnica e a saúde. Tese de doutorado. Faculdade de M edicina, U niversidade de São Paulo.

\section{Sobre a re-significação do humanismo}

On the re-signification of humanism

Vera Vidal 4

Nosso comentário ao texto de Ana M aria Aleksandrowicz e M aria Cecília M inayo terá o seguinte percurso: abordaremos seu aspecto estrutural e discutiremos a parte conceitual.

No que tange ao primeiro aspecto, cremos que o texto é muito bem escrito, claro, bem organizado logicamente e de leitura muito agradável. Parece-nos, entretanto, que seu objetivo principal, que deveria ser a re-significação do termo "humanismo", não foi plenamente atingido, ficando aquém do esperado e do enunciado. As considerações finais, muito sintéticas, não retomaram, de modo exaustivo, os dados, tanto da análise histórica efetuada, quanto da posição de Atlan, em vista de uma efetiva proposta que desse uma nova significação ao termo em questão.

Foi sugerido um apoio às correntes que revitalizaram as noções de progresso e perfectibilidade do homem, mas sem especificar quais são estas correntes e que argumentos sustentam tais posições; foi valorizada a interdisciplinaridade bem como as visões holísticas no tratamento das questões humanísticas; recorreuse a Spinoza como modelo de um bom tratamento para conciliar a visão naturalista do homem com a sua natural busca de perfeição e seu sentimento natural de ser autônomo nas decisões e, assim, superar a dicotomia dos estudos humanísticos e os das ciências da natureza; foi proposta uma solução positiva que seria exercida pela educação e por regimes políticos democráticos, favorecendo o uso dos avanços científicos em prol da melhoria geral da qualidade de vida e da felicidade dos homens; mas tudo isto dito em termos muito gerais, sem que percebêssemos como se justificam teórica e pragmaticamente tais sugestões.

Parece-nos também que deveria ter sido re tomado, de modo mais detalhado e explícito, nas considerações finais, um item importante que fora enunciado no início do texto: a relação desta discussão com o conjunto de questões no quadro dos estudos de saúde coletiva.

M uito nos agradou o percurso histórico efetuado sobre a evolução do conceito de natureza

\footnotetext{
4 Departamento de Pesquisa, Casa de O swaldo Cruz, Fiocruz. Veravidal2000@hotmail.com
} 